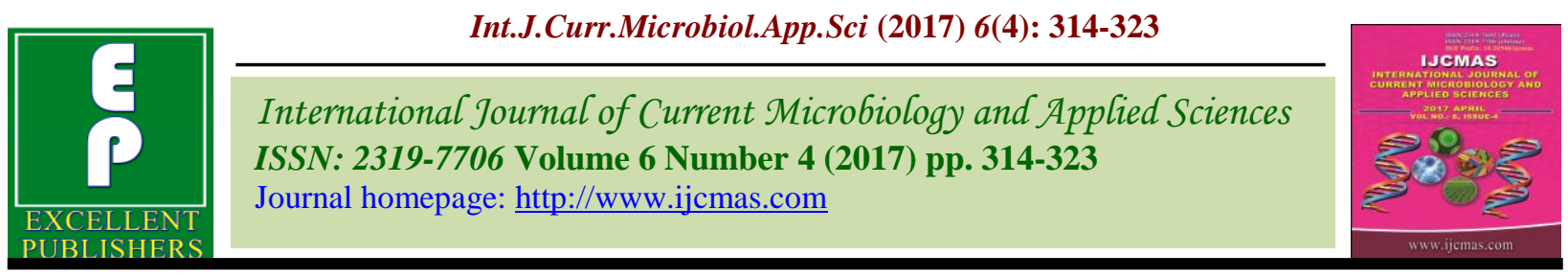

Original Research Article

https://doi.org/10.20546/ijcmas.2017.604.034

\title{
Characteristic Study on Biochar Production from Biological Substrates by Slow Pyrolysis for Carbon Sequestration
}

\author{
R. Shalini ${ }^{1}$, S. Pugalendhi ${ }^{1}$, P. Subramanian ${ }^{1}$ and N.O. Gopal ${ }^{2}$ \\ ${ }^{1}$ Department of Bioenergy, AEC \& RI, Tamil Nadu Agricultural University, \\ Coimbatore- 641 003, Tamil Nadu, India \\ ${ }^{2}$ Department of Agricultural Microbiology, Tamil Nadu Agricultural University, \\ Coimbatore- 641 003, Tamil Nadu, India \\ *Corresponding author
}

\section{A B S T R A C T}

\section{Keywords}

Agricultural residues, Slow pyrolysis, Biochar,

Total carbon content and Carbon sequestration, Green house gas mitigation.

Article Info

Accepted: 02 March 2017 Available Online: 10 April 2017
This present study compares the characteristics of biochars produced by slow pyrolysis at $400-450^{\circ} \mathrm{C}$ for the biological substrates namely, Coccus nucifera shells (CNS) and Prosopis glandulosa hard wood (PGH). Biochar yield of the biomass substrates varied from 25-28 \%. C/N ratio and Cation Exchange Capacity (CEC) was found to be higher in PGH biochar as 11.25 and 16.70 cmolkg-1 respectively. Thermo gravimetric analysis (TGA) of CNS derived biochar showed maximum yield of biochar of about $83.75 \%$ when compared to PGH biochar. It was inferred that before and after biochar production the materials were differed much in their physical, chemical, nutrient, thermal and biological characteristics, particularly total carbon content varied from 49 to $61 \%$. From this study, the carbon sequestration potential of the biochar was calculated as 2635 tonnes of $\mathrm{CO}_{2}$ reduction per year.

\section{Introduction}

Growing concerns on shrinking of fossil fuel resources has led to increased fuel costs which in turn lead to climate change issues which pays greater attention for the need of alternate energy fuels. As a result of photosynthesis, biomass is the only formed renewable resource which provides about $14 \%$ of global energy needs that is capable to substitute fossil fuels (Kaygusaz, 2002). Among the various energy conversion routes, thermochemical conversion technique can be used to generate fuel in different forms. In recent days, different approaches are coming up based on pyrolysis related bioenergy transformation processes. By selecting proper operation temperatures, pyrolysis can be focused on the production of solid (Slow pyrolysis: 400 to $500^{\circ} \mathrm{C}$ and hydrothermal carbonization: 180 to $220^{\circ} \mathrm{C}$ ) products, liquid (Fast pyrolysis: $900^{\circ} \mathrm{C}$ ) and gaseous (Gasification: $1100^{\circ} \mathrm{C}$ ) (Digman et al., 2009).

This study focuses on production of biochar, a carbon-rich solid material which is formed 
from biomass through a process called slow pyrolysis. Pyrolysis is induced by heating the biomass in the absence of oxygen condition and the temperature is about $500^{\circ} \mathrm{C}$ (Demirbas and Arin, 2002). In addition to the biochar, the process also results in bio oil and syngas that are used for further combustion and renewable fuels (Kwapinski et al., 2010). Low heating rate and long residence time are often used to increase solid products yield. Biochar produced from agricultural and forestry residues can be readily used as biofuel feed stocks for cooking, barbecue and existing coal power plants (Kung et al., 2013). It is superior in quality to coal-char due to its low sulfur content and high reactivity.

Biochar is not only used as a fuel, but also it can be used as the soil amendment that undergoes carbon sink which turns bioenergy into carbon-negative industry (Lehmann, 2007). Due to its higher porous structure, when applied in soil, it improves the physicochemical properties of soil, crop yields, soil structure, chemistry, ecology and reduces use of herbicides in soil (Laird, 2008). Biochar also delays the decomposition and biological carbon cycle mineralization to evolve a carbon sink. This in turn helps in net carbon withdrawal from the environment up to 20 per cent. Thus, it paves the way in the mitigation of GHG emissions by $12-84 \%$ (Lehmann, 2007). Hence production and utilization of biochar in the agricultural fields would reduce the damages to the environment and economically competitive when compared with other coal derived products (Garcia et al., 2012).

This paper focuses on production of biochar from $\mathrm{CNS}$ and $\mathrm{PGH}$ at the pyrolysis temperature range between 400 and $450^{\circ} \mathrm{C}$ which follows semi indirect heating method. The thermo gravimetric analysis was performed to investigate the pyrolytic characteristics and essential components that were present in the biochar. The properties of both the raw biomass and biochar such as proximate, ultimate, physico-chemical, nutrient and other important properties were studied, analyzed and compared for carbon sequestration potential in the atmosphere to mitigate green house emissions.

\section{Materials and Methods}

\section{Biochar production}

Biological substrates such as CNS and PGH were collected from the premises of Tamil Nadu Agricultural University, Coimbatore. They were cut down into $10-15 \mathrm{~cm}$ length and then dried in the solar tunnel dryer for 48 h. Later, the biological substrates were slowly pyrolyzed in the pyrolysis unit between 400 and $450^{\circ} \mathrm{C}$ by using semi-indirect heating method. The biochar were cooled, collected and then grounded down to about $<0.25 \mathrm{~mm}$ sieve for further characterization (IBI, 2010).

All the important properties of both the selected biological substrates and biochar were analyzed using the standard methods. Physical properties such as bulk density, porosity, particle density and texture were analyzed using the Keen Raczkowski brass cup method suggested by Richards (1954). The proximate analysis of the samples were determined using standard test methods such as ASTM E-830, 871, 872 to calculate ash content, moisture content and volatile matter respectively.

The ultimate analysis such as total carbon, hydrogen and oxygen was calculated using correlation analysis suggested by Parikh et al., (2007) and total nitrogen was estimated using Bremner method (Jackson, 1973). The calorific value was determined by using bomb calorimeter Elico, India (Jain, 1992). The pH and EC (Elico, India) and CEC of the biochar 
samples were determined using standard chemical methods (Crooke, 1964). The major and minor nutrient contents were determined by standard chemical methods. Thermo gravimetric experiments were carried out by feeding the biomass and biochar samples to the thermo gravimetric analyzer (Q50, TA Instruments, US) and the testing conditions were controlled under a nitrogen atmosphere at a temperature up to $1000^{\circ} \mathrm{C}$ to maintain inert condition with a heating rate at $10^{\circ} \mathrm{C}$ $\min ^{-1}$ (Josea et al., 2010).

\section{Different methods for carbon determination}

Carbon content of the biochar was determined by the wet digestion method (Walkley and Black, 1934). The total organic carbon content of the biochar was found out by taking a known quantity of dried biochar sample in an open crucible and keeping it in a muffle furnace at about $400^{\circ} \mathrm{C}$ for 3 to $4 \mathrm{~h}$ (Mitchell, 1932). Elemental carbon content in the biomass and biochar samples was determined using correlation analysis suggested by Parikh et al., (2007).

\section{Results and Discussion}

The different properties such as physicochemical, thermal and organo-chemical properties of both raw biomass and biochar samples were analyzed and its results were discussed in the tables given below.

Proximate and ultimate composition of biological substrates

The proximate and ultimate composition of the parent biomass samples were given in table 1 .

The volatile matter for the CNS and PGH biomass was initially higher with 73.5 and $75 \%$ respectively. However, more ash content was found in CNS biomass as $2.00 \%$ when compared to PGH biomass sample as 1 $\%$. Initially fixed carbon content of the biomasses were in the range of $25 \%$. The elemental carbon content of $\mathrm{CNS}$ and $\mathrm{PGH}$ biomasses was about $49.5 \%$ initially. The higher heating value of $\mathrm{CNS}$ and $\mathrm{PGH}$ biomass was found to be in the range of 18-19 MJ $\mathrm{kg}^{-1}$ which was on par with the results reported by Parikh et al., (2005).

\section{Characterization of biochars}

\section{Proximte compositon of biochars}

But after biochar production of both the samples between 400 and $450^{\circ} \mathrm{C}$, the volatile content was decreased from 75 to $11 \%$. The major constituents of biomass $(\mathrm{C}, \mathrm{H}$ and $\mathrm{O})$ volatilize during dehydration and pyrolysis with $\mathrm{H}$ and $\mathrm{O}$ being lost in proportionally greater amounts of $\mathrm{C}$. The $\mathrm{O}$ and $\mathrm{H}$ are lost initially as water and later as hydrocarbons, tarry vapours, $\mathrm{H}_{2}, \mathrm{CO}$ and $\mathrm{CO}_{2}$ (Antal and Gronli, 2003). From this result, it inferred that biochar contain less volatile compounds when compared to parent biomass; which ultimately results in $30-33 \%$ of biochar production. These results are in agreement with Graetz and Skjemstad (2003) and Demirbas (2004).

As per FAO (1985), the volatile matter in the biochar can vary from 5 to $40 \%$. But the fixed carbon content in biochar increases when compared with initial biomass. Fixed carbon content of CNS derived biochar was found to be maximum as $86 \%$ when compared to $\mathrm{PGH}$ biochar. This is because, during pyrolysis process around $50 \%$ of the carbon is retained with charred biomass. However, the recovery rates are dependent on the operating conditions of the pyrolysis process (Laird, 2008). So, higher carbon content was found to exist in the less charring temperature at 400$450^{\circ} \mathrm{C}$ resulting in larger biochar yield (\%). These trail result trails were on par with FAO 
(1985) report the fixed carbon content in the biochar may vary from 50 to $95 \%$.

\section{Physical properties of biochars}

The porosity of the PGH biochar was found to be higher as $74.70 \%$. Biochar has great potential to sequester atmospheric carbon dioxide through the physical parameter, the key factor in driving the functions within the soil (Downie et al., 2009). The biochar particle density was in the range of 1.88 to $2.06 \mathrm{~g} \mathrm{~cm}^{-3}$. Difference in biochar particle size lies in the range of 2 to $20 \mathrm{~mm}$ which has a significant influence on crop yield (Lehmann et al., 2003). Bulk density of both the biochars was found to be same as $0.50 \mathrm{gcm}^{-3}$. Pore space was maximum (74.7 per cent) in the PGH biochar produced at biochar which results in higher water holding capacity.

The surface area of the biochar is determined by its porosity which varies from 0.9 to $50 \mathrm{~nm}$ (Downie et al., 2009). The $\mathrm{pH}$ of biochar ranged from 9.64 to 9.90 and the maximum $\mathrm{pH}$ was found in $\mathrm{PGH}$ biochar. Biochar are used as a soil amendment with the $\mathrm{pH}$ usually alkaline in nature $(\mathrm{pH}>7.0)$. The $\mathrm{pH}$ values of the biochar produced from pyrolysis process were ranged between 4 and 12 and the results were satisfied with Lehmann (2007). EC of the biochars were varied from 1.20 to $1.70 \mathrm{dS} \mathrm{m}^{-1}$.

The EC is an index of salt loading indicates that the biochar contained a very low amount of salt. CEC of biochars widely ranged from 11.50 to $16.70 \mathrm{cmol} \mathrm{kg}^{-1}$. Maximum CEC was found to be in PGH biochar as $16.70 \mathrm{cmol} \mathrm{kg}^{-1}$. The nutrient retention ability of cations present in biochar is dependent upon their cation exchange capacity. CEC proved to be very low at low pyrolysis temperatures and increases significantly at higher temperature
(Lehmann, 2007). Freshly produced biochar have proven minimal CEC compared to soil organic matter (Cheng et al., 2006). The results indicated that depending on the feedstock, biochar produced from CNS and PGH have the potential to serve as nutrient sources as well as to sequester carbon.

\section{Ultimate analysis of biochars}

Elemental carbon content of the biochar ranged from 59.5 to $60.78 \%$. The evolving nature of the carbonaceous residue obtained when lignocellulosic biomass is thermally degraded under various conditions. Whereas, Antal and Gronli (2003) reported that the C content increases from 40 to $50 \%$ by weight in the feedstock to on the order of 70 to $80 \%$ by weight after pyrolysis between $250^{\circ} \mathrm{C}$ and $600^{\circ} \mathrm{C}$. Elemental hydrogen ranged from 5.29 to $5.34 \%$. Elemental oxygen content ranged from 32.42 to $33.49 \%$.

Elemental nitrogen content for both the biochars were found to be $0.84 \%$. Biochar yield of the biomass substrates varied from $20-25 \%$ by weight while it was recorded as 25-28\% from the organic fraction after mass optimization. Thus, the maximum biochar yield was $27.5 \%$ by weight for CNS biochar when compared to PGH biochar which implies that if the temperature increases biochar yield also increases.

Energy content is strongly related to chemical and physical composition of the biomass and can be estimated by either proximate or elemental analyses data for a range of biomass types (Erol et al., 2010). The rate of increase in temperature has high influences on product yield. The higher heating value (HHV) of the biochar samples ranged from 27.81-28.85 $\mathrm{MJ} \mathrm{kg}^{-1}$ which is higher than that of coal $\left(24 \mathrm{MJ} \mathrm{kg}^{-1}\right)$. 
Table.1 Proximate and ultimate composition of biological substrates

\begin{tabular}{|c|c|c|}
\hline Properties & CNS Biomass & PGH Biomass \\
\hline \multicolumn{3}{|c|}{ Proximate Composition (wt.\% dry basis) } \\
\hline Volatile matter & 73.50 & 75.00 \\
\hline Ash content & 2.00 & 1.00 \\
\hline Fixed carbon & 24.50 & 24.00 \\
\hline \multicolumn{3}{|c|}{ Ultimate Composition (wt.\% dry basis) } \\
\hline Carbon & 49.04 & 49.41 \\
\hline Hydrogen & 5.83 & 5.89 \\
\hline Nitrogen & 1.27 & 0.93 \\
\hline Oxygen & 42.43 & 42.99 \\
\hline $\mathrm{HHV}, \mathrm{MJ} \mathrm{kg}^{-1}$ & 18.92 & 18.82 \\
\hline
\end{tabular}

Table.2 Characterization of biochars

\begin{tabular}{|c|c|c|}
\hline & CNS Biochar & PGH Biochar \\
\hline \multicolumn{3}{|l|}{ Physical Properties } \\
\hline Bulk density $\left(\mathrm{g} \mathrm{cm}^{-3}\right)$ & 0.55 & 0.50 \\
\hline Porosity $(\%)$ & 68.60 & 74.70 \\
\hline \multicolumn{3}{|c|}{ Proximate Composition (wt.\% dry basis) } \\
\hline Volatile matter & 13.20 & 19.60 \\
\hline Ash content & 0.80 & 0.90 \\
\hline Fixed carbon & 86.00 & 79.50 \\
\hline \multicolumn{3}{|c|}{ Ultimate Analysis (wt.\% dry basis) } \\
\hline Carbon & 60.78 & 59.55 \\
\hline Hydrogen & 5.29 & 5.34 \\
\hline Nitrogen & 0.84 & 0.84 \\
\hline Oxygen & 32.42 & 33.49 \\
\hline $\mathrm{HHV}\left(\mathrm{MJ} \mathrm{kg}^{-1}\right)$ & 28.85 & 27.81 \\
\hline Biochar Yield $(\% \mathrm{wt})$ & 27.50 & 24.86 \\
\hline \multicolumn{3}{|c|}{ Organo - chemical Properties (Atomic ratio) } \\
\hline H/C Ratio & 0.087 & 0.089 \\
\hline $\mathrm{O} / \mathrm{C}$ Ratio & 0.53 & 0.56 \\
\hline \multicolumn{3}{|c|}{ Electrochemical Properties } \\
\hline $\mathrm{pH}$ & 9.64 & 9.80 \\
\hline $\mathrm{EC}\left(\mathrm{dS} \mathrm{m}^{-1}\right)$ & 1.20 & 1.70 \\
\hline $\mathrm{CEC}\left(\mathrm{cmol} \mathrm{kg}^{-1}\right)$ & 11.50 & 16.70 \\
\hline \multicolumn{3}{|l|}{ Major Nutrients (\%) } \\
\hline Nitrogen $(\mathrm{N})$ & 1.12 & 0.84 \\
\hline Phosphorus (P) & 0.21 & 0.07 \\
\hline Potassium $(\mathrm{K})$ & 0.96 & 1.03 \\
\hline \multicolumn{3}{|l|}{ Minor Nutrients (\%) } \\
\hline Sodium $(\mathrm{Na})$ & 0.66 & 0.70 \\
\hline Calcium $(\mathrm{Ca})$ & 1.60 & 4.24 \\
\hline Magnesium (Mg) & 0.24 & 0.99 \\
\hline Organic Carbon $(\%)$ & 1.05 & 9.45 \\
\hline C/N Ratio & 0.935 & 11.25 \\
\hline
\end{tabular}


Table.3 Comparison of the decomposition of biochars with biomass feedstocks

\begin{tabular}{|l|l|l|l|l|}
\hline Thermal properties & CNS Biomass & CNS Biochar & PGH Biomass & PGH Biochar \\
\hline $\begin{array}{l}\text { Temperature at the } \\
\text { maximum yield of } \\
\text { decomposition }\left(\mathrm{T}_{\max },{ }^{\circ} \mathrm{C}\right)\end{array}$ & 375 & 250 & 402 & 156 \\
\hline $\begin{array}{l}\text { Maximum yield of } \\
\text { decomposition at } \\
800-1000^{\circ} \mathrm{C}\left(\mathrm{min}^{-1}\right)\end{array}$ & 0.050 & 0.020 & 0.092 & 0.037 \\
\hline $\begin{array}{l}\text { Remaining solid residue } \\
(\%)\end{array}$ & 49.00 & 83.75 & 39.80 & 80.10 \\
\hline
\end{tabular}

Fig.1 TG and DTG plots of Coccus nucifera shells at a heating rate of $10{ }^{\circ} \mathrm{C} \mathrm{min}^{-1}$

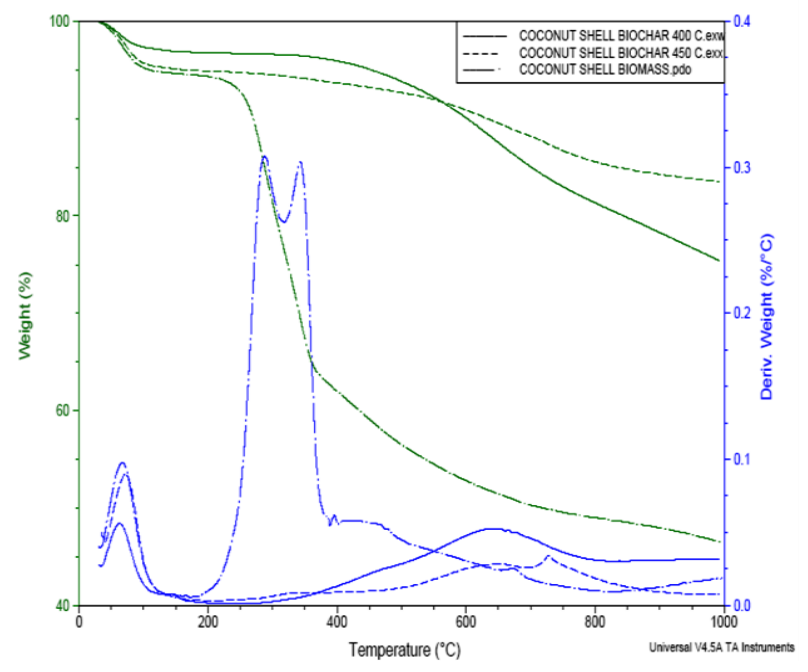

Fig.2 TG and DTG plots of Prosopis glandulosa sp. at a heating rate of $10{ }^{\circ} \mathrm{C} \mathrm{min}{ }^{-1}$

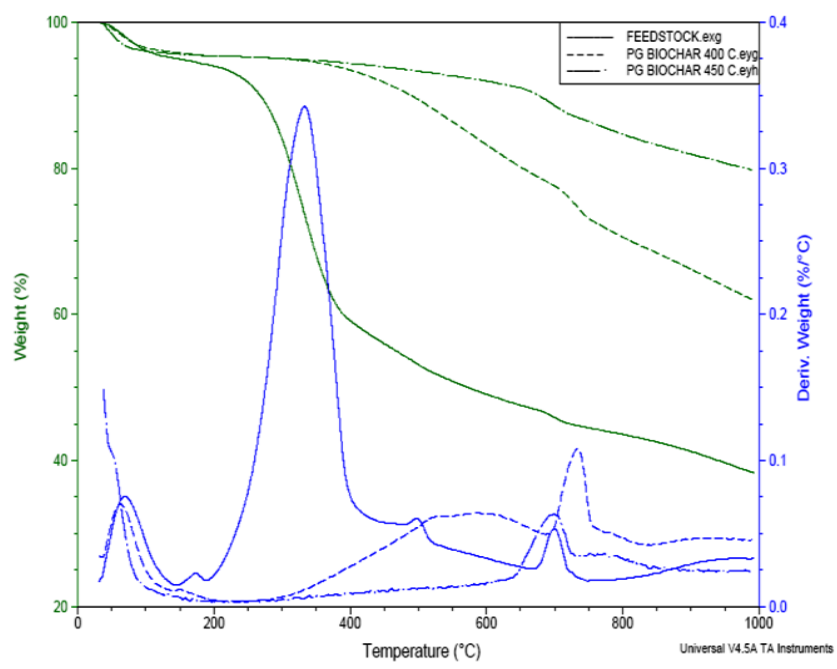




\section{Determination of organic carbon in biochar samples}

Carbon is the chief element present in biochar and it varies from 40 to $98 \%$ depending upon the nature of feedstock / biological material used. It is the single most character that determines the properties of biochar and has essential potential as an element of agricultural and environmental importance. The accurate measurement of $\mathrm{C}$ in biochar is a prerequisite for its effective application in environmental management. Being agro residue, most of the $\mathrm{C}$ in biochar is in the form of organic C. However, a number of studies have shown that the proportion of $\mathrm{C}$ in biochar is highly variable with the type of biological materials as it differs in their $\mathrm{C}$ content.

The organic carbon was estimated by using wet oxidation by chromic acid method resulted the range from 1.05 to $9.45 \%$. The results reported were consistent with the work of Rondon et al., (2007).

\section{Organo-chemical properties}

The elemental $\mathrm{H} / \mathrm{C}$ ratios for $\mathrm{CNS}$ and $\mathrm{PGH}$ biomass were initially 0.118 and 0.119 . O/C ratios were from 0.86 and 0.87 respectively. The Hydrogen to Carbon and Oxygen to Carbon ratios of CNS and PGH biochars varied from 0.08 to 0.5 respectively. The ratios were decreased after biochar production when compared to initial biomass feed stocks as reported by Almendros et al., (2003) that Hydrogen to Carbon and Oxygen to Carbon ratios in experimentally obtained biochar yield was decreased with increase in temperature and time. The $\mathrm{H} / \mathrm{C}$ and $\mathrm{O} / \mathrm{C}$ ratios were used to measure the percentage of aromaticity and maturation of biochar (Baldock and Smernik, 2002). Sometimes, temperatures during biomass burning are greater than $400^{\circ} \mathrm{C}$ and the chars formed during these temperatures are likely to have $\mathrm{H} / \mathrm{C}$ ratios of $\leq 0.5$. This type of biochars and burning residues had significantly higher $\mathrm{H} / \mathrm{C}$ ratios (Schmidt and Noack, 2000).

The initial parental $\mathrm{C} / \mathrm{N}$ ratio of the $\mathrm{CNS}$ and PGH were found to be about 38.61 and 53.1. The $\mathrm{C} / \mathrm{N}$ ratio was calculated using total carbon and nitrogen content of the CNS and PGH biochars. The $\mathrm{C} / \mathrm{N}$ was found to be higher in biochars when compared to raw biomass. Higher $\mathrm{C} / \mathrm{N}$ ratio was found in PGH biochar as 11.25. These values were similar as reported by Cheng et al., (2006). This ratio is acts as an indicator of inorganic $\mathrm{N}$ release by mineralization of organic substrates. $\mathrm{C} / \mathrm{N}$ ratio of 20 for organic substrates is used as a critical limit above which immobilization of $\mathrm{N}$ by microorganisms occurs, therefore, the $\mathrm{N}$ applied with the substrate is not available to plants.

\section{Nutrient properties}

The total major and minor nutrient concentrations of biomass and biochar materials were depicted in table 2 . Total N, P and $\mathrm{K}$ contents of CNS and PGH biomasses varied from 0.93 to $1.27,0.11$ to 0.12 and 1.07 to 1.68 respectively. Similarly, total N, P and $\mathrm{K}$ contents of the biochars varied from 0.84 to $1.12,0.07$ to 0.21 and 0.96 to $1.03 \%$ respectively. Higher total $\mathrm{N}$ content was found to be as $1.12 \%$ in CNS biochar. The $\mathrm{Na}, \mathrm{Ca}$ and $\mathrm{Mg}$ concentrations ranged between 0.24 and $4.24 \%$ in the biochar samples. The concentration of total nutrients in biochar was totally influenced by the respective feedstocks. Biochars contained nutrients $(\mathrm{P}, \mathrm{K}, \mathrm{Ca}$ and $\mathrm{Mg}$ ) were in higher concentrations. But Gaskin et al., (2008) reported that total $\mathrm{N}$ (1.8 to $56.4 \mathrm{~g} \mathrm{~kg}^{-1}$ ), total $\mathrm{P}$ (2.7 to $480 \mathrm{~g} \mathrm{~kg}^{-1}$ ) and total $\mathrm{K}$ (1.0 to $58 \mathrm{~g}$ $\mathrm{kg}^{-1}$ ) was higher when compared to this study. A larger portion of $\mathrm{N}$ was retained within the biochar (27.4\%) in poultry litter biochar and 
$(89.6 \%)$ in pine chip biochar obtained at 400 and $500^{\circ} \mathrm{C}$. The volume of $\mathrm{N}$ retained in the biochar was observed to be inversely proportional to the $\mathrm{N}$ concentration in biomass (Chan and $\mathrm{Xu}, 2009$ ). During low temperature $\left(<500^{\circ} \mathrm{C}\right)$ slow pyrolysis, $\mathrm{P}$ and $\mathrm{K}$ typically accumulate on the biochar product in a bio-available form (Hossain et al., 2007).

\section{Thermo Gravimetric Analysis (TGA)}

Figures 1 and 2 show the mass loss curve (TG) i.e., weight loss versus temperature of different biomass and biochar samples. The graphs also show the presence of a secondary peak in this area representing the least volatile fraction of the sample, mainly hemicellulose. The last stage is solid decomposition at a temperature range of $600-900^{\circ} \mathrm{C}$. At this stage, the weight is lost slowly. Table 3 shows a comparison of the decomposition of biochar samples with the decomposition of raw biomass samples. The difference in thermal degradation of biochar samples was observed.

An initial loss of mass was detected at $110^{\circ} \mathrm{C}$ and then a steady drop in weight of sample beyond the peak heating temperature. From table 3 , it can be seen that the temperature at the maximum yield $\left(173^{\circ} \mathrm{C}\right)$ for $\mathrm{PGH}$ biochar decomposition is lower than that of the other biochar samples, which indicates that the pyrolysis reaction for that sample can occur easier.

The maximum yield for the decomposition is lower than that for the other biomass sources (Vuthaluru, 2004) which indicates that the amount of volatile matter from PGH biochar is lower than that from raw biomass sources. However, the PGH biochar was low when pyrolysis ended than when compared to the CNS biochar produced between $400-450^{\circ} \mathrm{C}$.

From the results, it is concluded that the optimum temperature for biochar production is about $400-450^{\circ} \mathrm{C}$ to obtain maximum yield (\%) of biochars. Since biochars are rich in carbon content, they can be used as an alternate for solid fuel applications. If this biomass derived biochars are applied in the soil, it is calculated from the study that about 2,653 tonnes of carbon dioxide can be reduced in the atmosphere per year (Tonnes of $\mathrm{CO}_{2}$ reduction per $\mathrm{yr}^{-1}$ ). Also, at the same time, addition of biochar to soils can enhance fertility leading to increased crop yield or allowing reduced application of energyintensive agrochemicals. Clearly, further research is needed to be established in the area for optimizing the process parameters for biochar production using different processes and technologies and also to optimize the characteristics of biochar for agricultural applications to create inherent multiple benefits to the environment.

\section{Acknowledgement}

The authors sincerely thank the Department of Soil Sciences, Department of Environmental Sciences, Department of Microbiology, Department of Nanoscience and Technology for guiding and carrying out the research work at their esteemed laboratories and we indeed obliquely thank the Department of Bioenergy, Tamil Nadu Agricultural University, Coimbatore, India for providing funding support and guidance to carry out the research activities.

\section{References}

Almendros, H., Knicker and F.J. Gonzalez Vila. 2003. Rearrangement of carbon and nitrogen forms in peat after progressive thermal oxidation as determined by solid-state and N-NMR spectroscopy. Organic Geochem., 34: 559-1568.

Baldock and R.J. Smernik. 2002. Chemical composition and bioavailability of 
thermally altered Pinusresinosa (Red pine) wood. Organic. Geochem., 33: 1093-1109.

Chan and Z. Xu. 2009. Biochar: Nutrient properties and their enhancement. In: J. Lehmann and S. Joseph. Eds.), Biochar for Environmental Management: Science and Technology. Earthscan, London, pp. 67-81.

Cheng, J. Lehmann and J. Thies. 2006. Oxidation of black carbon by biotic and abiotic processes. Organic Geochem., 37: $1477-88$.

Crooke. 1964. The measurement of the cation- exchange capacity of plant roots. Plant Soil, 21: 43-49.

Demirbas. 2003. Sustainable co-firing of biomass with coal. Energy Conversion Manage., 44: 1465-1479.

Demirbas. 2004. Effects of temperature and particle size on biochar yield from pyrolysis of agricultural residues. $J$. Anal. Appl. Pyrolysis, 72(2): 243.

Demirbas and G. Arin. 2002. An Overview of Biomass Pyrolysis. Energy Sources, 24: 471 - 482.

Downie, A. Crosky and A. Munroe. 2009. Physical properties of biochar. In: Lehmann, J., Joseph, S. Eds.), Biochar for Environmental Management: Science and Technology. Earthscan, London, pp. 173.

Erol, H., Haykiri-Acma and S. Kucukbayrak, S. 2010. Calorific value estimation of biomass from their proximate analyses data. Renewable Energy, 35: 170-173.

Food and Agriculture Organization of the United Nations - FAO. 1985. Industrial charcoal making, FAO Forestry Paper No. 63, FAO, Rome.

Gaskin, C., Steiner, K., Harris, K.C., Das and B., Bibens. 2008. Effect of low-temperature pyrolysis conditions on bio-char for agricultural use. ASABE, 51(6): $2061-2069$.

Graetz and J.O. Skjemstad. 2003. The charcoal sink of biomass burning on the Australian continent. CSIRO Marine and Atmospheric Res., Technical paper No. 64.

Hossain, V. Strezov and P. Nelson. 2007. Evaluation of agricultural char from sewage sludge. In: Proceedings of conference on International Agrichar Initiative. Terrigal, Australia. held at Terrigal, NSW, Australia, $30^{\text {th }}$ April to $2^{\text {nd }}$ May. pp. 39.

Jackson. 1973. Soil Chemistry Analysis. Prentice Hall of India. Pvt.) Ltd., New Delhi.

Jain. 1992. Fuel Wood Characteristics of Certain Hardwood and Softwood Tree Species in India. Biores. Technol., 41: $129-133$.

Josea, E., Granada, A., Saavedra, P., Eguia and J. Collazo. 2010. Biomass Thermogravimetric Analysis: Uncertainty Determination Methodology and Sampling Maps Generation. Int. J. Mol. Sci.,11(7): 2701-2714.

Kaygusaz and M.F. Turker. 2002. Biomass and Energy Potential in Turkey. Biomass and Bioenergy, 26: 661- 678.

Kumar, L. Wang, Y.A. Dzenis, D.D. Jones and M.A. Hanna. 2008. Thermogravimetric characterization of corn stover as gasification and pyrolysis feedstock. Biomass and Bioenergy, 32: 460 - 467.

Kwapinski. 2010. Biochar from Biomass and Waste. Waste Biomass Valor, pp. 177189.

Laird. 2008. The Charcoal Vision: A Win Scenario for Simultaneously Producing Bioenergy, Permanently Sequestering Carbon, while Improving Soil and Water Quality. Agron., 100: 178 - 181.

Lehmann. 2007. Handful of Carbon. Nature Publishing Group, pp. 143-144.

Lehmann, D., Kern, D. German, L., McCann, J. Martins and G. Moreira. 2003. Soil 
fertility and production potential. In: Amazonian Dark Earths: Origin, Properties, Management. Eds. J. Lehmann, D.C. Kern, B. Glaser and W.I. Woods) Kluwer Academic Publishers, Netherlands, pp.105.

Liang, J., Lehmann, J., Solomon, D., Kinyangi, J., Grossman, J.O., Neill, B., Skjemstad, J.O., Thies, J., Luizao, F.J., Petersen and J. Neves. 2006. Black carbon increases cation exchange capacity in soils. American J. Soil Sci., 70: 1719-1730.

Mitchell. 1932. The origin, nature and importance of soil organic constituents having base exchange properties. $J$. American Society for Agron., 24: 256 275.

Parikh, S.A. Channiwala and G.K. Ghosal. 2007. A correlation for calculating elemental composition from proximate analysis of biomass materials. Fuel, 86: 1710-1719.

Pathak. 1984. Characteristics of crop residues. Energy Digest, 7 - 10.

Richards. 1954. Diagnosis and improvement of saline and alkali soils. USDA Handbook No. 60.pp. 160.

Rondon, J. Lehmann, J. Ramirez and M. Hurtado. 2007. Biological nitrogen fixation by common beans. Phaseolus vulgaris L) increases with biochar additions. Biol. Fertility of Soils, 43: 688-708

Schmidt and A.G. Noack. 2000. Black carbon in soils and sediments: analysis, distribution, implications, and current challenges. Global Biogeochem. Cycle, 14: 77-94.

Varshney, L. Bhagoria and C.R Mehta. 2010. Small scale biomass gasification technology in India.- An overview. $J$. Engi. Sci. Manage. Edu., 3: 33 - 40.

Vuthaluru. 2004. Investigations into the pyrolytic behaviour of coal/biomass blends using thermogravimetric analysis. Biores. Technol., 92: 187-195.

Walkley and C.A. Black. 1934. An estimation of methods for determining organic carbon and nitrogen in the soils. J. Agri. Sci., 25: 598-609.

\section{How to cite this article:}

Shalini, R., S. Pugalendhi, P. Subramanian and Gopal, N.O. 2017. Characteristic Study on Biochar Production from Biological Substrates by Slow Pyrolysis for Carbon Sequestration. Int.J.Curr.Microbiol.App.Sci. 6(4): 314-323. doi: https://doi.org/10.20546/ijcmas.2017.604.034 